\title{
Influence of Arm Movement on Lesion Detection in PET/CT Imaging: Case Report
}

\author{
PET/BT Görüntülemede Kol Hareketinin Lezyon Dedeksiyonu Üzerine Etkisi: Olgu Sunumu
}

Yasemin Parlak, Gozde Mutevelizade, Gul Gumuser, Elvan Sayit

Celal Bayar University Faculty of Medicine, Department of Nuclear Medicine, Manisa, Turkey

\begin{abstract}
Arm movement after the CT scan is a common artifact in PET/CT scanning. Motion artifacts may lead to difficulties in interpreting PET/CT images accurately. We report a 66 year old male patient with gastric cancer who underwent PET/CT for primary staging. He had a previous history of papillary thyroid cancer. In PET scan, there were striking cold artifacts at the level of arms. This is a classical sign of an accidental arm motion. A second scan was performed with the arms down due to the history of papillary thyroid cancer. The results were discussed.
\end{abstract}

Key Words: Arm movement, artifact, PET/CT

Conflicts of Interest: The authors reported no conflict of interest related to this article.

\section{Özet}

PET/BT görüntülemede BT tarama sonrası kol hareketi sık karşılaşılan bir artefakttır. Hareket artefaktları doğru şekilde PET/BT raporlandırmada zorluklara neden olabilir. Mide kanserli 66 yaşındaki erkek hastaya evreleme amacıyla PET/BT yapıldı. Hastanın aynı zamanda papiller tiroid kanseri öyküsü mevcuttu. PET taramada kol seviyesinde çizgili soğuk artefaktlar mevcuttu. Bu durum istemsiz kol hareketinin bir göstergesiydi. Hastada mevcut papiller tiroid kanseri öyküsü nedeniyle kollar aşağıda olacak şekilde ikinci bir tarama yapılarak sonuçlar değerlendirildi.

Anahtar Kelimeler: Kol hareketi, artefakt, PET/BT

Çıkar Çatışması: Yazarlar bu makale ile ilgili olarak herhangi bir çıkar çatışması bildirmemiştir.

\section{Introduction}

Integrated PET/CT (positron emission tomography/ computed tomography) with a high-resolution anatomical imaging modality can resolve the localization issue, as long as the images from the two modalities are accurately coregistered. The data are complementary, allowing CT to accurately localize functional abnormalities and PET to highlight areas of abnormal metabolism. Accurate anatomical and functional images can be obtained by minimizing patient movement between CT and PET scans, and accounting for the axial separation of the two modalities $(1,2)$.
For many clinical PET/CT studies, whole-body acquisition is commonly performed with the patient's arms raised above the head. Arm motion typically gives rise to spatial misalignment between the CT and PET data $(3,4,5)$. Here in, we present a patient with a similar phenomenon in his arms on PET/CT scan.

\section{Case Report}

A 66-year-old male patient with gastric cancer underwent PET/CT imaging for primary staging. The

Address for Correspondence: Yasemin Parlak PhD, Celal Bayar University Faculty of Medicine, Department of Nuclear Medicine, Manisa, Turkey Phone: +90 5352560685 E-mail: yasemin.gultekin@hotmail.com Received: 01.07.2014 Accepted: 23.12.2014 
patient also had a history of papillary thyroid cancer. He had undergone total thyroidectomy in March 2013, and mediastinotomy due to a mediastinal mass (metastasis of thyroid papillary cancer) in May 2013. The patient had $6475 \mathrm{MBq}$ (175 mCi) I-131 ablation therapy in August and bilateral residual thyroid tissues were detected on postablation whole body l-131 scan. Consequently, follow-up with TSH suppression was recommended. On November 2013 the patient had abdominal pain and was diagnosed with gastric cancer. He underwent PET/CT imaging for primary staging of gastric cancer.

The intravenous injection of $277 \mathrm{MBq}(7.5 \mathrm{mCi})$ FDG was performed with the arms positioned above the patient's head. Approximately $60 \mathrm{~min}$ later, a PET/CT examination was obtained from mid thigh to skull base with a Truflight Select PET/CT system (Philips Medical Systems, USA).

CT acquisition (16-slice; $120 \mathrm{kVp} ; 80 \mathrm{~mA}$ ) from the base of the skull to mid thigh was immediately followed by multibed PET acquisition (lutetium yttrium orthosilicate crystals; 3-dimensional 3D acquisition; 180 s per bed position; 5 bed positions) in the caudo-cranial direction.

PET images were reconstructed using 3D ordered subsets expectation maximization as appropriate, in conjunction with the parameters described for the clinical protocol.

The primary tumor $(19 \times 14 \mathrm{~mm})$ was on the gastric wall (SUVmax: 10.9). Also, there was an increased FDG uptake at the left side of larynx (SUVmax: 6.5). Detailed examination was made by oto-rhino-laryngology specialist and no pathological finding was detected.

Striking cold artifacts evident at the arm level were detected on PET/CT image. He moved his arms during the acquisition of the whole-body PET scan. A delayed imaging focused on the patient's neck was additionally performed, with the arms down, due to these artifacts. The neck scan revealed increased F-18 FDG uptake (SUVmax: 5.4) at the right cervical lymph node (level 7). This activity was not observed in the first scan due to the artifact (Figure 1). The existence of hypermetabolic cervical lymph node in the patient with thyroid $\mathrm{Ca}$ affected follow-up and therapeutic management of the patient. After the detection of the metastatic cervical lymph node, recurrent I-131 therapy was planned.

\section{Discussion}

PET is a non-invasive imaging modality that is widely used both for diagnosis and assessing therapy response in oncology, cardiology and neurology clinics (6). The diagnostic accuracy of PET scans has been shown to significantly increase with the use of $C T$, in staging of malignant disease as well as identification and localization of metastases (7). It is a valuable tool to recognize malignant nodules, owing to its high sensitivity $(6,8)$. There are several artifacts in PET/CT imaging, including attenuation correction (AC) artifacts associated with using $\mathrm{CT}$ for $\mathrm{AC}$. There is an algorithm to convert the correction factors from CT to PET in all PET/CT systems. The measured CT Hounsfield units, related to the linear attenuation seen by the x-ray beam, must be transformed into the corresponding quantity at the higher PET photon energy of $511 \mathrm{keV}(9)$.

This case report was prepared to evaluate the effect of arm motion artifacts in combined PET/CT. We have tried to characterize the cause of the artifacts and to investigate the effect of arm motion on lesion detection. Arm motion artifacts might arise when performing the PET/CT scan with the arms positioned above the patient's head during the acquisition of data.

This artifact manifested as a striking underestimation of the reconstructed image signal throughout multiple transverse slices, and appeared as cold bands in the coronal and sagittal images at the level of arm motion. These cold areas caused doubt in the distribution of F-18 FDG.

When the arms are positioned by the patient, CT images could show significant beam hardening and streak artifacts in the posterior abdomen, caused by increased beam attenuation from the upper extremities $(1,2,3,4)$. Arm movement after CT scan is a commonly seen artifact in PET scanning. When a patient moves his/her arms after CT scan, it results in significant reconstruction artifacts. The change in arm position causes severe reconstruction artifacts over the chest, central abdomen, and pelvis, corresponding to the misalignment of PET emission data from the CT-based attenuation map. This can lead to striking cold artifacts on PET images $(2,4)$.

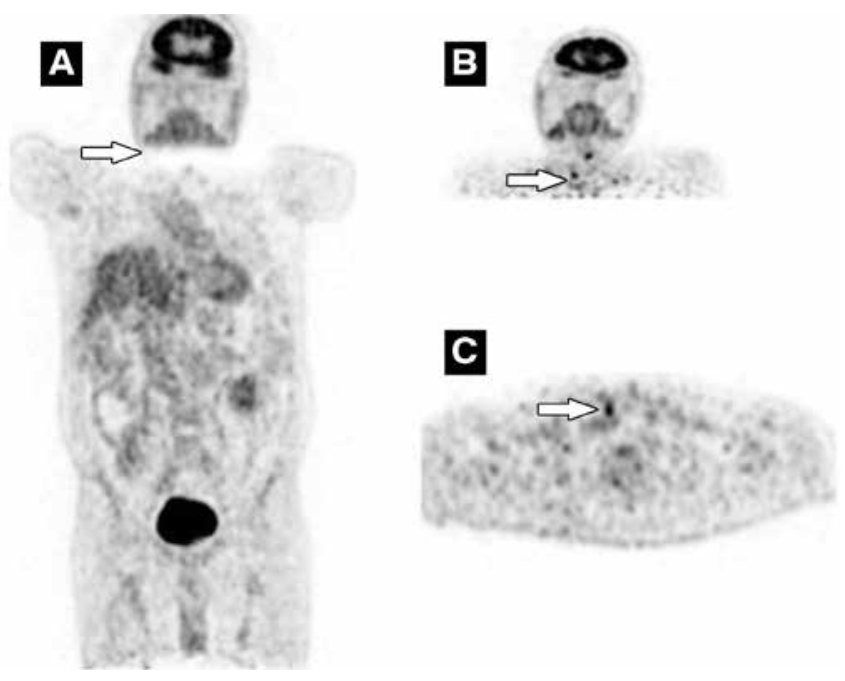

Figure 1. PET image with $C T$ attenuation correction. The PET/CT image showed cold artifacts evident at arm level (A). Delayed image, with the arms down, focused on the patient's neck. The arrow shows the cervical lymph node that was not observed in the first scan due to the artifact $(B, C)$ 


\section{Conclusion}

Arm position may decrease the accuracy of attenuation correction and image quality. Therefore, when a PET/CT scan is performed, it is crucial that the technician should position the patient at the center of the field of view, and carefully place the patient's arms above the head. We suggest performing a second examination focused on the neck, this time with the arms down, in patients with head and neck malignancies, thyroid Ca or clinical suspicion of neck involvement. The arm motion of the patient can cause substantial artifacts in PET images.

\section{References}

1. Blodgett TM, McCook BM, Federle MP. Positron Emission Tomography/Computed Tomography: Protocol Issues and Options. Semin Nucl Med 2006;36:157-168.
2. Callahan J, Binns D, Deller T, Hicks RJ. Scatter Limitation to Correct for Arm Movement in PET/CT. Clin Nucl Med 2012;37:786-787.

3. Lodge MA, Mhlanga JC, Cho SY, Wahl RL. Effect of Patient Arm Motion in Whole-Body PET/CT. J Nucl Med 2011;52:1891-1897.

4. Beyer T, Antoch G, Müller S, Egelhof T, Freudenberg LS, Debatin J, Bockisch A. Acquisition Protocol Considerations for Combined PET/ CT Imaging, J Nucl Med 2004;45:25-35.

5. Townsend DW. Positron Emission Tomography/Computed Tomography. Semin Nucl Med 2008;38:152-166.

6. Pettinato C, Nanni C, Farsad M, Castellucci P, Sarnelli A, Civollani S, Franchi R, Fanti S, Marengo M, Bergamini C. Artefacts of PET/CT images. Biomed Imaging Interv J 2006:2:60.

7. Kresnik E, Mikosch P, Gallowitsch HJ, Kogler D, Wiesser S, Heinisch M, Unterweger O, Raunik W, Kumnig G, Gomez I, Grünbacher G, Lind P. Evaluation of head and neck cancer with 18F-FDG PET: a comparison with conventional methods. Eur J Nucl Med 2001;28:816-821.

8. Sureshbabu W, Mawlawi O. PET/CT Imaging Artifacts. J Nucl Med Technol 2005;33.156-161.

9. Blodgett TM, Mehta AS, Mehta AS, Laymon CM, Carney J, Townsend DW. PET/CT artifacts. Clin Imaging 2011;35:49-63. 